\title{
The Effect of Endurance, Eye-Hand Coordination, and Confidence to Volleyball Referee Performance in West Java
}

\author{
Subarna ${ }^{1, *}$, James Tangkudung", Moch Asmawi ${ }^{1}$, Anggi Setia Lengkana ${ }^{2}$, Aam Ali Rahman², \\ Ruslan Abdulgani ${ }^{3}$, Defri Mulyana ${ }^{4}$, Benny Badaru ${ }^{5}$ \\ ${ }^{1}$ Sport Education Program, Post Graduate Program, Universitas Negeri Jakarta, Indonesia \\ ${ }^{2}$ Physical Education of Elementary Teacher Program, Universitas Pendidikan Indonesia, Bandung, Indonesia \\ ${ }^{3}$ Physical Education, Health and Recreation Program, The Faculty of Teacher Education, Universitas Singaperbangsa, Karawang, \\ Indonesia \\ ${ }^{4}$ Physical Education Program, The Faculty of Teacher Education, Universitas Siliwangi, Tasikmalaya, Indonesia \\ ${ }^{5}$ Physical Education, Health and Recreation Program, The faculty of Sports Science, Universitas Negeri Makassar, Makassar, Indonesia
}

Received January 28, 2021; Revised March 17, 2021; Accepted April 18, 2021

\section{Cite This Paper in the following Citation Styles}

(a): [1] Subarna, James Tangkudung, Moch Asmawi, Anggi Setia Lengkana, Aam Ali Rahman, Ruslan Abdulgani, Defri Mulyana, Benny Badaru, "The Effect of Endurance, Eye-Hand Coordination, and Confidence to Volleyball Referee Performance in West Java," International Journal of Human Movement and Sports Sciences, Vol. 9, No. 3, pp. 436 - 444, 2021. DOI: 10.13189/saj.2021.090307.

(b): Subarna, James Tangkudung, Moch Asmawi, Anggi Setia Lengkana, Aam Ali Rahman, Ruslan Abdulgani, Defri Mulyana, Benny Badaru (2021). The Effect of Endurance, Eye-Hand Coordination, and Confidence to Volleyball Referee Performance in West Java. International Journal of Human Movement and Sports Sciences, 9(3), 436 - 444. DOI: 10.13189/saj.2021.090307.

Copyright $\bigcirc 2021$ by authors, all rights reserved. Authors agree that this article remains permanently open access under the terms of the Creative Commons Attribution License 4.0 International License

\begin{abstract}
A sports competition is a measure of success for an athlete. However, factors affecting an athlete's success come from the athlete and all competition aspects, including referees. Referees need to have a good reputation before and after carrying out their role as court judges. A referee must have competencies, including refereeing skills, rules of the game/competition, physical condition, mental-psychological conditions (self-confidence, calm, consistency, the assertiveness of attitudes and actions, accuracy in weighing and deciding, high motivation, honest $\&$ sincere, socializing). Thus, this research aims to examine the effect of physical conditions, primarily components of endurance, eye-hand coordination, and self-confidence, as psychological aspects that strengthen the referee's performance. To achieve this research's objectives, a survey method was used using path analysis and measurement techniques in tests through standard performance evaluation of volleyball referees, confidence questionnaires, 12 minutes running fitness test, and eye-hand coordination. The population involved in this research was 335 referees who had regional and national
\end{abstract}

diplomas. The sample of this research used the Slovin pattern with an error rate of $10 \%$, so that the sample amounted to 77 volleyball referees in West Java. The conclusions of this research are (1) Endurance affects the performance of the referee by $42.9 \%$, (2) Eye-hand coordination affects the performance of the referee by $39.6 \%$, (3) Confidence affects the performance of the referee by $45.8 \%$, (4) Endurance affects self-confidence by $51.2 \%$, (5) Eye-hand coordination affects self-confidence by $40.8 \%$.

Keywords Endurance, Eye-Hand Coordination, Confidence, Physical Fitness, Volleyball Referee Performance

\section{Introduction}

The referee's role in competitive sports is significant because in any sports game rules, no matter how small the 
field is used by one sport, one or two referees must be refereed with several assistants. It is in line with opinion [1] that referees are a crucial part of competitive sports. Referees and officials are a vital part of a sports competition because of their impact on players' behaviors and game outcomes and because they ensure that matches are conducted safely according to specific rules [2].

Due to how vital the referee's role is in a sports competition, a referee must have competence. Reference [3] states that a referee must have competencies, including refereeing skills, game/match rules, physical condition, mental-psychological conditions (self-confidence, calm, consistency, the assertiveness of attitudes and actions, accuracy in weighing and deciding, high motivation, honest \& sincere, sociable). References [4], [5] also stated that referee efficacy beliefs are hypothesized to be influenced by mastery of the game, knowledge/education of the referee, support from significant others, physical/mental preparedness, environmental comfort, and perceived anxiety. Accordingly, these beliefs may influence referee performance, referee stress, athlete rule violations, athlete satisfaction, and co-referee satisfaction. Reference [6] believes that besides having to master the game's knowledge, a referee must also have physical and mental readiness because they significantly affect his performance. Further, reference [7] found many physiological and personal factors influencing referees' performance. This psychological factor affecting a volleyball referee's performance when leading a match includes anxiety, stress, excitement, self-confidence, and motivation [8].

The failure in volleyball referees' performance in leading a match has recently occurred in volleyball matches, from low-level championships to higher-level championships even for the Indonesian Volleyball Association (PBVSI). The performance of the referee is the effect of work that is overwhelmed and is influenced by the competence of the referee himself, including having refereeing skills, having knowledge of the rules of the game/competition, having the proper physical condition, having mental-psychological, one of which is the level of self-confidence.

With the various problems that occur in the field, of course, it has an impact on decreasing public trust in the performance of volleyball referees, so that many reveal and always question both among players, officials, audiences, and even the mass media, that the performance of referees is currently still less good, especially when leading the match. As a consequence of the constant decision-making, referees' subjectivity when assessing actions, and the mistakes they may make, they are often criticized for their decisions. This criticism may come from the players, coaches, sports managers, fans, or sports media [9]. It can be interpreted that as a consequence of his actions when making wrong decisions, a referee is often criticized by players, coaches, sports managers, fans, and the sports media. As a result of frequently receiving criticism and even blasphemy continuously, of course, it will impact the mental health, so that in the end, it can worsen his performance. Based on reference [10], referees are constantly under pressure with consequent anxiety, stress, and confidence loss. These negative emotions that affect their mental health have been directly related to referees' dropout, loss of attention, low performance, and job satisfaction.

The problem is that the referee is often seen as the culprit for every incident on the field. This circumstance has become a general picture in our society, making the refereeing profession in Indonesia increasingly cornered. It underlies the researcher to find out more about the community's opinions, especially regarding the referee's performance who leads the match in each championship. Despite the fact, not all referees act as described.

Federation Internationale De Volleyball manages the physical fitness and good phycological condition of a referee (FIVB), that all the referees must be prepared to fulfill their duties in the best physical and psychological state. All professional referees must understand the significance and importance of their performance for modern volleyball [11]. The most crucial physical condition component possessed by a volleyball referee compared to other parts is endurance. This fitness component is an essential component that a volleyball referee must have because good endurance will increase the referee's strength when leading a match. The level of endurance is fundamental and by the referee's needs who is constantly faced with modern matches or fast-paced games because when endurance increases, he will have the strength and endurance to carry out the task of leading the game without experiencing significant fatigue.

As stated by references [12], [13] the level of endurance is fundamental and by the needs of the referee who is constantly faced with modern matches or fast-paced games, because when the endurance increases, he will have the strength and endurance to carry out the task of leading the match without experiencing significant fatigue. As explained in the volleyball rules, there are several hand signals for the referee, and the referee must be able to apply according to the field's mistakes. Hand gestures must be made quickly, so it requires good eye-hand coordination - eyes to see events that involve the coordination of the retina and extra retina. Reference [14] stated that hand-eye coordination depends on a combination of retinal and extraretinal signals necessary for accurate movement. Meanwhile, hands give the signal for errors [15].

Considering the matters mentioned above, this research aims to analyze how the role of endurance fitness and eye-hand coordination affects volleyball referees' performance in West Java Province, Indonesia. The referee is another figure in the field because he also has to have physical fitness like competing players. Referees 
have an additional challenge, namely, when they have to stay focused during the match, where the closer to the end of the match, the referee is like a player, getting tired. It makes endurance a significant role because the better the endurance, the better the focus, and vice versa [16]-[18]. Likewise, the better the endurance and eye-hand coordination, the better the level of trust, so it will significantly affect the referee's performance as a whole.

Previous studies have been recorded regarding the performance of referees in a match. Reference [19] found that stress has a significant impact on the performance of most sports referees. Meanwhile, reference [20] found that being a referee is very vulnerable to pressure both inside and outside the match. However, previous studies have not explained physical fitness in this case in the context of the bio-motoric components of endurance in referee performance. Therefore, researchers are trying to fill the gap by analyzing the level of endurance in volleyball referees to improve referees' performance to be more professional and reliable.

\section{Theoretical Framework}

\subsection{Referee Performance}

Performance is a result of work achieved by a person following their duties and responsibilities, and performance is something that people do and can be observed. As reference [21] defined, performance is work application, work implementation, work achievement, or work result. This performance is a work result that can be achieved by a person following their respective responsibilities to achieve the goals of the organization concerned legally, does not violate the law, and is under morals and ethics [22]. Also, reference [23], [24] said that performance is also defined as achieving specific job requirements, which can ultimately be reflected in the output produced. Moreover, performance is a) something achieved, b) demonstrated, c) workability [25], [26]. Everyone will certainly have a performance following his or her duties and responsibilities. Likewise, a volleyball referee, of course, has the responsibility of implementing the rules of the game in the field when leading a match [27].

By giving the right and accurate decisions when carrying out his duties leading a match, of course, it will have an impact on the professional performance of the referee so that he will be respected by players, coaches, and other officials [28]. Of the various tasks, some of the essential components must be implemented by a volleyball referee when carrying out his duties in the field, including paying attention to various events that occur in the field related to game rules (service position and player, ball touch, net area), player appearance and personality, match management and organization [29],[30].
By referring to some expert opinions and the Federation Internationale De Volleyball (FIVB) as described above, the authors decided that the sub-variables of volleyball referee performance consisted of service and player position, control of touch of the ball, netplay, appearance and personality, match management, match organization. Furthermore, as explained earlier, that a referee can carry out his duties properly when supported by various factors, including refereeing skills, rules of the game/competition, physical condition, mental-psychological conditions (self-confidence, calm, consistency, the assertiveness of attitudes and actions, accuracy in weighing and deciding, high motivation, honest $\&$ sincere, socializing).

\subsection{Endurance}

The maximum performance of a referee when leading a match needs to be supported by top physical fitness. Of the several physical fitness components above, the most important is cardiorespiratory endurance. This cardiorespiratory endurance is a crucial component in physical fitness and also a description of the degree of physical fitness that is owned. It is in line with Badriah's opinion, which states that cardiorespiratory endurance is a significant factor in physical fitness and is often synonymous with the notion of physical fitness itself. A person's physical fitness is reflected in the magnitude of V02 max, which describes cardiovascular endurance [31].

Among the four physical fitness components (cardiorespiratory endurance, muscular endurance, muscle strength, and flexibility), cardiorespiratory endurance is considered the most crucial physical fitness element [32]. Thus, the most important physical fitness element related to health is cardiorespiratory endurance / aerobic conditions. Cardiovascular endurance is the heart system's ability, pulmonary blood vessels to function optimally at rest and work to take oxygen and distribute it to active tissues to be used in the body's metabolic processes. General endurance is the body's ability to do activities for a long time without experiencing excessive fatigue after doing it, and this general endurance is the development of the cardiovascular system or the respiratory system [31], [33].

Based on the several opinions above, it can be concluded that general endurance is a significant factor in physical fitness. Therefore, researchers have concluded that this cardiorespiratory endurance can represent the degree of physical fitness or physical condition possessed by a volleyball referee.

\subsection{Eye-Hand Coordination}

The coordination used in this research is hand-eye coordination, which is the vision system's ability to coordinate the information received through the eyes to control, direct the hands (both hands) in completing a given 
task, such as in a volleyball referee. It gives the referee's signal. Meanwhile, hand-eye coordination is the vision system's ability to coordinate the information received through the eyes to control, guide, and mind direct the hands to accomplish a given task [34].

Eye-hand coordination is essential in overall physical development; throwing, hitting, pushing, and pulling skills require eye-hand coordination [35]. The coordination of eye and hand movements is our natural center that combines the ability to see and the ability of the hand, which depends on the retinal and extraretinal signals needed for accurate movement, for example, a volleyball referee beforehand movements to signal the eye should be pointing or the intended object, while the hand functions to control the movement to match the intended target [36]. It is confirmed by reference [37] that Coordinating eye and arm movements are central to our natural behavior. A referee must have excellent visual skills to capture in detail all the events on the field during a match [38]. From some of the opinions mentioned above, it can be concluded that eye-hand coordination is a combination of the eye and hand to perform a movement, the eye to see height, size, distance, target, and hand to control the force to be released in order to obtain a practical and effective movement.

\section{Materials and Methods}

\subsection{Research Design}

This research is a descriptive research that seeks to describe and interpret objects. It is also often called non-experimental. In this research, the researcher did not control and manipulate the research variables; with descriptive methods, the research made it possible to make the relationship between variables, test hypotheses, develop generalizations, and develop theories that have universal validity. The approach in this research uses a survey method with measurement and test techniques. The analysis technique is through path analysis, namely, researchers who will research or analyze the relationship between research variables and measure one variable's direct and indirect effects on another. The path analysis model analyzes the pattern of causal relationships between variables to determine the direct or indirect effect of a set of exogenous variables on endogenous variables. The following figure 1 is a constellation of the relationship pattern between the research variables.

The target population in this research were all referees in West Java, as many as 335 people. Meanwhile, the number of samples in this research was determined using the Slovin formula [39]. A total population of 335 volleyball referees spread across 22 districts/cities in West Java Province, it took samples of 77 referees. For the actual value obtained as a result of the research to be generalized to the existing population, it is necessary to observe various possibilities that may affect the research results: the research sample must have the same characteristics (homogeneous). They are:

a) The sample is registered as a volleyball referee in West Java.

b) The sample has a classification.

c) The sample has led a match or was assigned to referee volleyball matches at the city/regency, provincial and national levels.

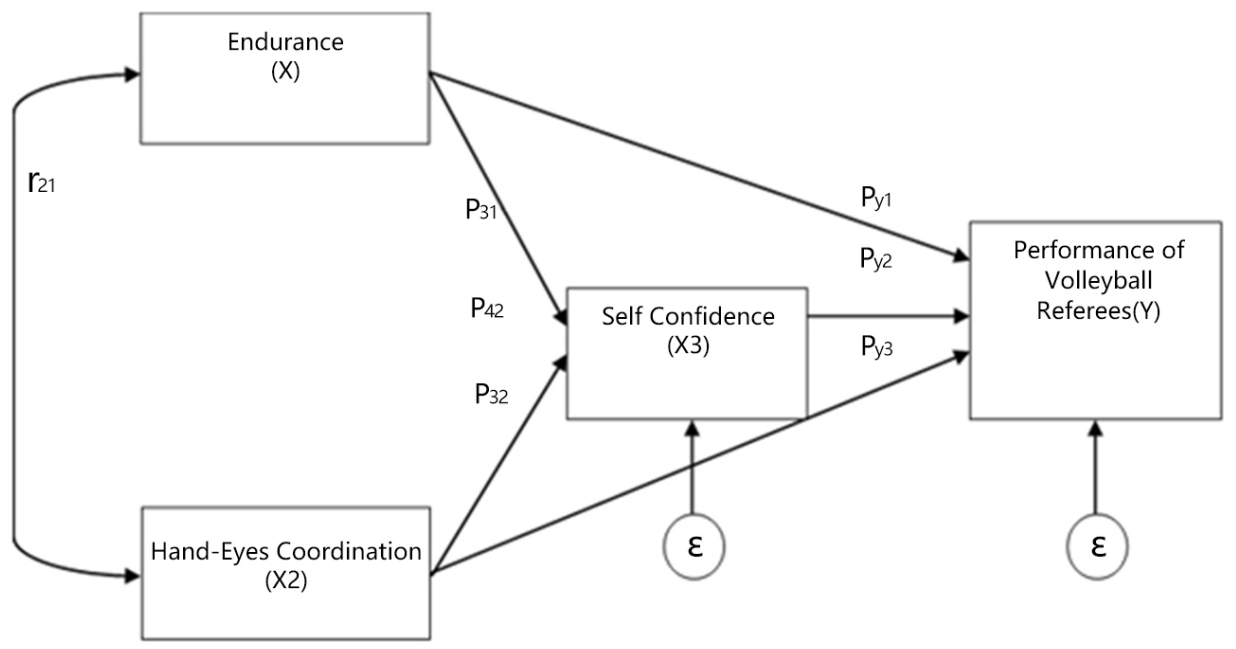

Figure 1. Research Variable Interconnection Patterns 


\subsection{Procedures}

The first step was to conduct observations and discussions with the Head of the Sports Supervision Division of the Indonesian Volleyball Association (PBVSI), West Java Province. From the results of the meeting, data were obtained from several cases that occurred at official regional matches in the West Java region; one of the teams did not want to continue the match because it was not satisfied with the referee's decision and asked the referee who was leading the match to be replaced with another referee. In another case, the match was stopped again because one of the teams thought the referee's decision was detrimental to his team. Based on the results of surveys, interviews, and volleyball referee evaluation sheets that researchers obtained from the SRC (Special Referee Committee) of West Java Province, it was found that there were still many mistakes made by referees when leading a match, especially in determining a decision.

After getting 77 samples, the samples were divided into two groups to facilitate the measurement process. One group is on the endurance test, one group is on the eye-hand coordination test, one group is filling out a confidential questionnaire, and another group is filling out the referee performance evaluation sheet.

\subsection{Research Instrument}

The data obtained in this research are the results of measuring the endurance and the performance of volleyball referees in West Java. The research instrument was pursued through several stages: (a) compiling the research variable indicators, (b) compiling the instrument grid, (c) testing the instruments, (d) testing the validity and reliability of the instruments. By the types of variables involved in the research, to obtain the data processed in this research, the instruments used were (1) the volleyball referee performance instrument $(\mathrm{Y})$ with a questionnaire. The questionnaire test was arranged according to the Guttman Scale (2) Endurance, (X) using the aerobic test copper, which is running without stopping for 12 minutes [40] and hand-eye coordination test [12] also, self-confidence questionnaires given to volleyball referees who were research respondents.

The dependent variable (response) in this research is the performance variable of volleyball referees in West Java using instruments made by the researchers themselves concerning the standard of performance evaluation of volleyball referees based on Federation Internationale De Volleyball (FIVB), including service players position, ball contact control (criteria, uniformity), play et the net, appearance and personality, game management, organization.

\section{Result}

\subsection{Normality Test Result}

The collected data were analyzed through statistical approaches both descriptively, inductively, and the relationship between variables. This research's statistical test step was the normality test using One-Sample Kolmogorov Smirnov with the SPSS for Windows application program's help.

Based on the table 2, data shows the results of the Kolmogorov-Smirnov Z test with Asymp.Sig (2-Tailed) values ranging from 0.051 to 0.711 . Because all variables have an asymp sig greater than 0.05 , it can be said that all the variables studied in this research were normally distributed, so that it is feasible to carry out further analysis using parametric statistics.

Table 1. Volleyball Referee Performance Variables

\begin{tabular}{|c|c|c|c|c|}
\hline $\begin{array}{c}\text { Research } \\
\text { Variable }\end{array}$ & Empirical Concept & Analytical Concept & Resouces & Scale \\
\hline $\begin{array}{c}\text { Volleyball } \\
\text { Referee } \\
\text { Performance }\end{array}$ & $\begin{array}{c}\text { A volleyball referee can lead a } \\
\text { match to provide satisfaction to } \\
\text { all elements involved in the } \\
\text { match. }\end{array}$ & $\begin{array}{c}\text { Special Referee Commission (SRC) assessment of } \\
\text { volleyball referees' ability to provide services to players or } \\
\text { all the match elements. The instruments used are under the } \\
\text { performance standards of the Federation Internationale De } \\
\text { Volleyball (FIVB) volleyball referee }\end{array}$ & $\begin{array}{c}S R C \& \\
\text { Referee }\end{array}$ & Ordinal \\
\hline
\end{tabular}

Table 2. Normality test result

\begin{tabular}{ccc}
\hline Variable & Statistic Values & Significance \\
\hline Referee Performance & 1,360 & 0,051 \\
Hand-Eye Coordination & 1,342 & 0,059 \\
Endurance & 0,700 & 0,711 \\
Self Confidence Level & 1,198 & 0,113 \\
\hline
\end{tabular}




\subsection{Referee Performance}

In general, an overview of the referee's performance variables based on each indicator can be seen in table 3 .

Table 3. Percentage of Volleyball Referee Performance Score Achievement in West Java based on each indicator

\begin{tabular}{|c|c|c|c|c|}
\hline Indikator & $\begin{array}{l}\text { Total } \\
\text { Score }\end{array}$ & $\begin{array}{l}\text { Ideal } \\
\text { Score }\end{array}$ & $\begin{array}{c}\text { Achievability } \\
(\%)\end{array}$ & Note \\
\hline $\begin{array}{l}\text { Service, players } \\
\text { position }\end{array}$ & 363 & 385 & $94,3 \%$ & $\begin{array}{l}\text { Very } \\
\text { good }\end{array}$ \\
\hline $\begin{array}{l}\text { Ball contact } \\
\text { control (criteria, } \\
\text { uniformity) }\end{array}$ & 562 & 616 & $91,2 \%$ & $\begin{array}{l}\text { Very } \\
\text { good }\end{array}$ \\
\hline Play at the net & 672 & 770 & $87,3 \%$ & $\begin{array}{l}\text { Very } \\
\text { good }\end{array}$ \\
\hline $\begin{array}{c}\text { Appearance and } \\
\text { personality }\end{array}$ & 368 & 385 & $95,6 \%$ & $\begin{array}{l}\text { Very } \\
\text { good }\end{array}$ \\
\hline $\begin{array}{l}\text { Game } \\
\text { management }\end{array}$ & 558 & 616 & $90,6 \%$ & $\begin{array}{l}\text { Very } \\
\text { good }\end{array}$ \\
\hline Organisation & 353 & 385 & $91,7 \%$ & $\begin{array}{l}\text { Very } \\
\text { good }\end{array}$ \\
\hline
\end{tabular}

Based on the table above, it appears that the performance of volleyball referees in West Java, seen in each indicator, is in an outstanding category. Based on the table above, it also appears that the indicator with the highest achievement score is the appearance and personality indicator, namely $95.6 \%$. The indicator with the smallest achievement score is the play at the net indicator, which is $87.3 \%$. However, all of these indicators are still categorized as very good.

\subsection{Linearity and Regression Test}

Based on the data table of the linearity test results, it is known that the Sig. Deviation from linearity ranges from 0.162 to 0.670 . Because all variables have a value greater than 0.05 , it can be concluded that the regression linearity of the X1-Z, X2-Z, Y-Z, X1-Y, X2-Y variables in this research is linearly distributed.

From the data (table 5), it can be explained that the percentage obtained between $\mathrm{X} 1$ to $\mathrm{Z}$ is $0.429 \times 100 \%=$ $42.9 \%$. The percentage obtained between $X 2$ against $Z$ is $0.396 \times 100 \%=39.6 \%$. The percentage obtained between $\mathrm{Y}$ to $\mathrm{Z}$ is $0.458 \times 100 \%=45.8 \%$. The percentage obtained between $\mathrm{X} 1$ against $\mathrm{Y}$ is $0.512 \times 100 \%=51.2 \%$. The percentage obtained between $\mathrm{X} 2$ against $\mathrm{Y}$ is $0.408 \mathrm{x} 100 \%$ $=40.8 \%$.

To test the regression equation's validity, the t-test was carried out, so the tcount value between $X 1$ and $Z=3.251$ was obtained, the tcount value between $X 2$ and $Z=3.712$ was obtained, the tcount value between $Y$ and $Z=2.845$ was obtained. 2,948, obtained the value of tcount between $\mathrm{X} 2$ and $\mathrm{Y}=3.117$. In contrast, the value of $\mathrm{t}$ table $=1.990$. After comparing the value of $t$ count with $t$ table, it turns out that it is identified that $t$ count in the variables $X 1-Z$, $\mathrm{X} 2-\mathrm{Z}, \mathrm{Y}-\mathrm{Z}, \mathrm{X} 1-\mathrm{Y}, \mathrm{X} 2-\mathrm{Y}>\mathrm{t}$ table. So it can be concluded that the regression equation for the variables $X 1-Z, X 2-Z$, $\mathrm{Y}-\mathrm{Z}, \mathrm{X} 1-\mathrm{Y}, \mathrm{X} 2-\mathrm{Y}$ is significant.

Table 4. Summary of the Anova table Matrix Exposing the Linearity Test of Regression

\begin{tabular}{|c|c|c|c|c|}
\hline & Endurance $\left(\mathbf{X}_{\mathbf{1}}\right)$ & $\begin{array}{c}\text { Hand-eye } \\
\text { coordination }\left(\mathbf{X}_{\mathbf{2}}\right)\end{array}$ & $\begin{array}{c}\text { Self-confidence } \\
(\mathbf{Y})\end{array}$ & Referee performance $(\mathbf{Z})$ \\
\hline Endurance $\left(\mathbf{X}_{\mathbf{1}}\right)$ & 1 & - & $0.659^{* *}$ & $0,421^{* *}$ \\
\hline Hand-eye coordination $\left(\mathbf{X}_{\mathbf{2}}\right)$ & - & 1 & $0.602^{* *}$ & $0.670^{* *}$ \\
\hline Self-confidence $(\mathbf{Y})$ & $0.508^{* *}$ & $0.425^{* *}$ & 1 & $0,336^{* *}$ \\
\hline Referee performance $(\mathbf{Z})$ & $0,325^{* *}$ & $0,162^{* *}$ & $0,507^{* *}$ & 1 \\
\hline
\end{tabular}

Table 5. Variable Significance Matrics

\begin{tabular}{|c|c|c|c|c|c|c|c|c|}
\hline & \multicolumn{2}{|c|}{ Endurance $\left(\mathbf{X}_{1}\right)$} & \multicolumn{2}{|c|}{$\begin{array}{c}\text { Hand-eye } \\
\text { coordination }\left(\mathrm{X}_{2}\right)\end{array}$} & \multicolumn{2}{|c|}{ Self-confidence (Y) } & \multicolumn{2}{|c|}{$\begin{array}{c}\text { Referee performance } \\
(\mathrm{Z})\end{array}$} \\
\hline & Beta & $\mathrm{t}$ & Beta & $\mathrm{t}$ & Beta & $\mathrm{t}$ & Beta & $\mathrm{t}$ \\
\hline Endurance $\left(\mathbf{X}_{1}\right)$ & - & & - & - & .530 & - & .471 & - \\
\hline Hand-eye coordination $\left(X_{2}\right)$ & - & - & & & .432 & - & .521 & - \\
\hline Self-confidence (Y) & .512 & 3.251 & .408 & 3,712 & & & .374 & - \\
\hline Referee performance $(Z)$ & .429 & 2,948 & .396 & 3,117 & .458 & 2,845 & & \\
\hline
\end{tabular}




\subsection{Calculation of Path Coefficient on Sub-Structure 1}

The causal relationship between variables in Sub-Structure-1, which is shown in Figure 4.3 below, consists of one endogenous variable, namely $\mathrm{Y}$, and two exogenous variables, namely $\mathrm{X} 1$ and $\mathrm{X} 2$. The structural equation for sub-structure 1 is as follows: $\mathrm{Y}=\mathrm{rYx} 1 \mathrm{X} 1+$ $\mathrm{rYx} 2 \mathrm{X} 2$.

Table 6. Result of Calculation and Testing of Sub-structure Path Coefficient 1

\begin{tabular}{|c|c|c|c|c|c|}
\hline \multirow{2}{*}{ Path } & \multirow{2}{*}{ coefficient } & \multirow{2}{*}{ t-ob } & $t_{\text {tabel }}$ & Note & \multirow{2}{*}{$\begin{array}{c}\text { R Square } \\
\text { Change }\end{array}$} \\
\hline & & & \multicolumn{2}{|c|}{$\alpha=0,05$} & \\
\hline$\rho \mathrm{yx}_{1}$ & 0.424 & 2,946 & 1,990 & Sign & \multirow{2}{*}{0,879} \\
\hline$\rho \mathrm{yx}_{2}$ & 0.502 & 3.117 & 1,990 & Sign & \\
\hline
\end{tabular}

The amount of the coefficient $\mathrm{X} 1$ against $\mathrm{Y}(\rho \mathrm{yx} 1=$ $0.424)$. Then $X 2$ to $Y(\rho y x 2=0.502)$. Simultaneously reflected (contribution) $\mathrm{X} 1, \mathrm{X} 2$ to $\mathrm{Y}$ of (Rsquare = $\mathrm{R} 2 \mathrm{YX} 2 \mathrm{X} 1)=0.879$ or $87.9 \%$. Thus the structural arrangement equation for path diagram of the substructure 1 is $\mathrm{Y}=0.424 \mathrm{X} 1+0.502 \mathrm{X} 2+0.121 \varepsilon 1$. The path and the path coefficient value can be seen in the diagram as follows:

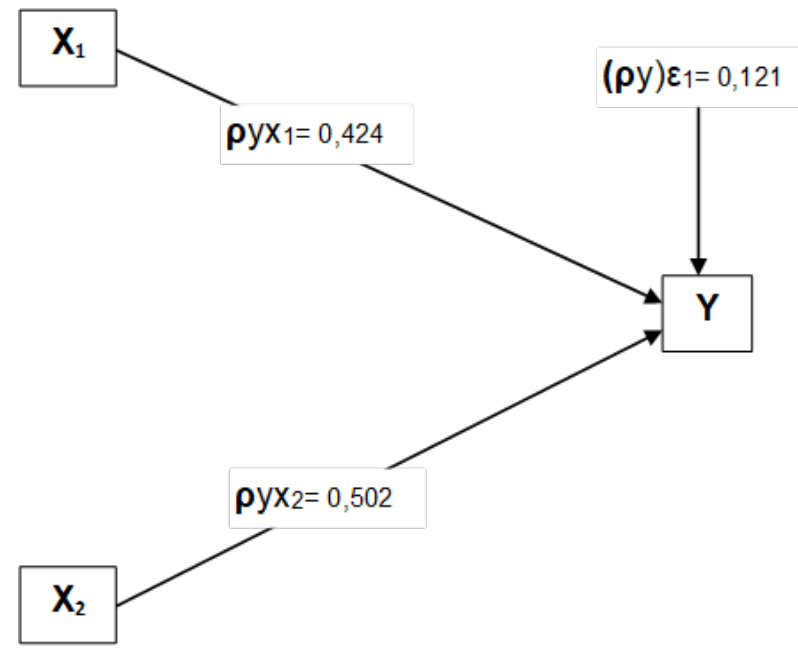

Figure 2. Sub-Struktur-1

\subsection{Calculation of Path Coefficient on Sub-Structure 2}

The causal relationship in Sub-Structure-2 consists of one endogenous variable, namely $Z$, and three exogenous variables, namely $\mathrm{X} 1, \mathrm{X} 2$, and $\mathrm{Y}$. The structural equation for sub-structure 2 is as follows:

Table 7. Result of Calculation and Testing of Sub-structure Path Coefficient 2

\begin{tabular}{|c|c|c|c|c|c|}
\hline \multirow{2}{*}{ Path } & \multirow{2}{*}{ coefficient } & \multirow{2}{*}{ t-ob } & $\mathbf{t}_{\text {tabel }}$ & Note & \multirow{2}{*}{$\begin{array}{c}\text { R } \\
\text { Square } \\
\text { Change }\end{array}$} \\
\cline { 4 - 5 } & & & \multicolumn{2}{|c|}{$\alpha=0,05$} & \multirow{2}{*}{0,762} \\
\hline$\rho \mathrm{zx}_{1}$ & 0.744 & 2,946 & 1,990 & Sign & \\
\hline$\rho \mathrm{zx}_{2}$ & 0.620 & 3.117 & 1,990 & Sign & \\
\hline$\rho z y$ & 0.532 & 2,845 & 1,990 & Sign & \\
\hline
\end{tabular}

The amount of the coefficient $\mathrm{X} 1$ against $\mathrm{Z}(\rho \mathrm{zx} 1=$ $0.744)$. Then $X 2$ against $Z(\rho z x 2=0.620)$. It is reflected (contribution) $\mathrm{X} 1, \mathrm{X} 2$ and $\mathrm{Y}$ simultaneously to $\mathrm{Z}$ of (Rsquare $=$ R2ZYX2X1) $=0.762$ or $76.2 \%$. Thus the structural arrangement equation for path diagram of the substructure 1 is $\mathrm{Y}=0.744 \mathrm{X} 1+0.620 \mathrm{X} 2+0.532 \mathrm{Y}+$ $0.238 \varepsilon 2$. The path and the path coefficient value can be seen in the following diagram:

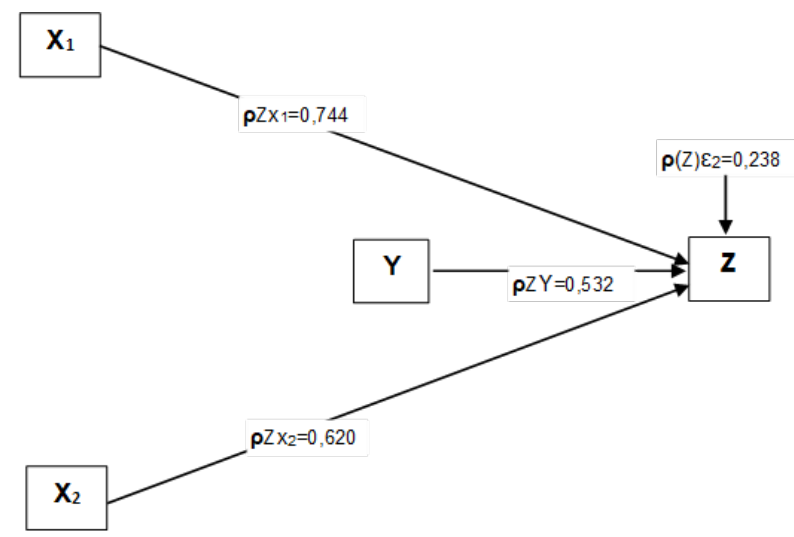

Figure 3. Sub-Struktur-2

\section{Discussion}

Endurance discussed is more emphasized on cardiorespiratory endurance, which is part of the components of physical fitness. This cardio-respiratory endurance is a significant factor in physical fitness and often becomes a synonym for the notion of physical fitness itself. In essence, this resistance is the body's ability to carry out activities for a long time without experiencing significant fatigue. A referee must have excellent cardiorespiratory endurance because he must lead the game from the start to the end of the match. Reference [40] explained that concentration, speed, physical fitness, the precision of reaction, anticipation, impartiality, and good cooperation with other officials are skills required to perform their expected duties successfully. Moreover, fitness has a significant effect on a person's performance while undergoing activities [10].

In the aspect of coordination, especially in eye-hand coordination, the eye's function becomes very central because the movements that the limbs will carry out are very dependent on the speed of the eyes in capturing stimuli (information) [41]. In other words, the suitability of the direction or movement pattern of the limbs is dependent on the information (object stimuli) that the eye can receive. So it can be concluded that the main completeness for perceiving an object that will provide information to then be processed into a gesture is visual perception (vision) [42]. A volleyball referee must be able to show what events he sees quickly when leading the match. If a volleyball referee has good eye-hand coordination, he will also have an excellent ability to signal his decision while leading a 
match [43].

Furthermore, psychological aspects, especially self-esteem affects referees' performance and becomes the core factor for them when referring the match. When particular situational demands are considered, self-efficacy can be defined as one's belief to accomplish behaviors resulting in desired consequences in a particular condition and ability to perform various levels of a task successfully [44]. Further, reference [45],[46] argues that psychological aspects such as self-confidence, concentration, and emotional control play a decisive role in referees' behavior and decisions and that psychology affects up to $70 \%$ of their success.

A referee who has high self-confidence will always be optimistic in carrying out his duties. A referee who has reasonable confidence will take attitudes and decisions calmly, correctly, and not in a hurry when leading a match.

\section{Conclusion}

Conclusions are drawn based on the research findings with exogenous variables consisting of Endurance, Eye-Hand Coordination (X), Intervening Confidence (Y), while the endogenous variable is the West Java Volleyball Referee Performance $(Z)$. Based on data analysis and statistical calculations in the previous chapter, it can be concluded: (1) Endurance affects the performance of the referee by $42.9 \%$, (2) Eye-hand coordination affects the performance of the referee by $39.6 \%$, (3) Confidence effect on the performance of the referee by $45.8 \%$, (4) Endurance has an effect on self-confidence by $51.2 \%$, (5) Eye-hand coordination has an effect on self-confidence by $40.8 \%$. Endurance, eye-hand coordination, self-confidence have a direct effect on the performance of West Java volleyball referees. It means that if there is an improvement in a volleyball referee's physical and psychological condition, it will increase the referee's performance in leading the match.

\section{Acknowledgments}

The author would like to thank all the referees in West Java province who were willing to spend their time, thoughts and energy during this research.

\section{REFERENCES}

[1] A. Karaçam and A. Pulur, "Examining the relationship between referee self-efficacy and general self-efficacy levels of football, basketball and handball referees," Univers. $J$. Educ. Res., vol. 5, no. 9, pp. 1571-1579, 2017.

[2] A. Karaçam and A. Pulur, "Identification the Relation between Active Basketball Classification Referees'
Empathetic Tendencies and Their Problem Solving Abilities.," Univers. J. Educ. Res., vol. 4, no. 8, pp. 19121917, 2016.

[3] K. Reid and C. Dallaire, " 'I'd like to think I'ma good referee': discourses of ability and the subjectivity of the female soccer referee in Ontario (Canada)," Soccer Soc., pp. 1-16, 2020.

[4] V. S. Mikhael, H. E. Elsheikh, S. T. El-Bakry, S. F. Abd-Elmaksoud, and others, "Burnout among nursing staff in Benha University Hospital," Egypt. J. Psychiatry, vol. 41, no. 3 , p. $153,2020$.

[5] G. Stulp, A. P. Buunk, S. Verhulst, and T. V Pollet, "High and mighty: Height increases authority in professional refereeing," Evol. Psychol., vol. 10, no. 3, p. $147470491201000320,2012$.

[6] D. Mascarenhas, D. O Hare, H. Plessner, and others, "The psychological and performance demands of association football refereeing," Int. J. Sport Psychol., vol. 37, no. 2/3, p. 99, 2006.

[7] P. SayfollahPour, "A Consideration of the Factors Influencing Soccer Referees' Judgment? An Overview," Int. J. Acad. Res. Bus. Soc. Sci., vol. 3, no. 5, p. 678, 2013.

[8] H. Aguirre-Loaiza et al., "Psychological characteristics of sports performance: Analysis of professional and semiprofessional football referees," J. Phys. Educ. Sport, vol. 20, no. 4, pp. 1861-1868, 2020.

[9] S. Russell, I. Renshaw, and K. Davids, "How interacting constraints shape emergent decision-making of national-level football referees," Qual. Res. Sport. Exerc. Heal., vol. 11, no. 4, pp. 573-588, 2019.

[10] P. Diotaiuti, L. Falese, S. Mancone, and F. Purromuto, "A structural Model of Self-efficacy in Handball Referees," Front. Psychol., vol. 8, p. 811, 2017.

[11] C. Reynaud, A. V. C. Association, and others, The Volleyball Coaching Bible, Volume II. Human Kinetics, 2015.

[12] D. Widiastuti and M. Pd, "Tes dan pengukuran olahraga," Jakarta PT. Bumi Timur Jaya, 2011.

[13] A. S. Lengkana, A. A. Rahman, M. N. Alif, G. Mulya, A. Priana, and D. B. Hermawan, "Static and Dynamic Balance Learning in Primary School Students," International Journal of Human Movement and Sports Sciences., vol. 8, no. 6, pp. 469-476, 2020. DOI: 10.13189/saj.2020.080620.

[14] G. Ziv, R. Lidor, S. Zach, S. Brams, and W. F. Helsen, "Gaze Behavior of Referees in Sport-A Review," Front. Sport. Act. Living, vol. 2, 2020.

[15] P. R. Sailors, S. Teetzel, and C. Weaving, "No Net Gain: A critique of media representations of women's Olympic beach volleyball," Fem. Media Stud., vol. 12, no. 3, pp. 468-472, 2012.

[16] D. Castillo, J. Yanci, J. A. Casajús, and J. Cámara, "Physical fitness and physiological characteristics of soccer referees," Sci. Sports, vol. 31, no. 1, pp. 27-35, 2016.

[17] J. A. Casajus and C. Castagna, "Aerobic fitness and field test performance in elite Spanish soccer referees of different ages,” J. Sci. Med. Sport, vol. 10, no. 6, pp. 382-389, 2007.

[18] G. Morris and D. O’Connor, “Key attributes of expert NRL 
referees," J. Sports Sci., vol. 35, no. 9, pp. 852-857, 2017.

[19] P. Briganti, L. Varriale, and M. Ferrara, "Stress and Sport: organizational practices to support referees forcoping stress," G. Ital. di Educ. alla Salut. Sport e Didatt. Inclusiva, vol. 2, no. 3,2018 .

[20] M. YAZICI and R. ÖZ, "LEISURE CONSTRAINTS OF VOLLEYBALL AND FOOTBALL REFEREES AND THEIR METHODS OF COPING WITH THEM," Acad. Stud. Sport Sci., p. 67.

[21] M. Zollo and D. Meier, "What is M\&A performance?," Acad. Manag. Perspect., vol. 22, no. 3, pp. 55-77, 2008.

[22] N. Arianty, "Pengaruh budaya organisasi terhadap kinerja pegawai," J. Ilm. Manaj. dan Bisnis, vol. 14, no. 2, 2015.

[23]R. Schechner, Performance studies: An introduction. Routledge, 2017.

[24] W. Kaydos, Operational performance measurement: increasing total productivity. CRC press, 2020.

[25] J. C. McDavid, I. Huse, and L. R. L. Hawthorn, Program evaluation and performance measurement: An introduction to practice. Sage Publications, 2018.

[26] A. S. Lengkana, J. Tangkudung, and A. Asmawi, “The Effect Of Core Stability Exercise (CSE) On Balance In Primary School Students," J. Educ. Heal. Sport, vol. 9, no. 4, pp. 160$167,2019$.

[27] J. P. Morillo, R. E. Reigal, A. Hernández-Mendo, A. Montaña, and V. Morales-Sánchez, "Decision-making by handball referees: design of an ad hoc observation instrument and polar coordinate analysis," Front. Psychol., vol. 8, p. $1842,2017$.

[28] K. E. Alsharji, M. F. Alkatan, A. A. Akbar, and H. A. Ahmad, "THE EFFECT OF REFEREEING AND PLAYING EXPERIENCE ON THE LEVEL OF SELF-EFFICACY FOR HANDBALL REFEREES: NATIONAL AND INTERNATIONAL REFEREES," DRASSA J. Dev. Res. Sport Sci. Act., vol. 5, no. 2, pp. 198-213, 2019.

[29] P. B. V. S. Indonesia, "Peraturan Bola Voli," Jakarta PB PBVSI, 2001.

[30] J. Jouny-Rivier, B. Walliser, and others, "La fédération internationale de Volleyball (FIVB) et sa campagne" FIVB Heroes"," 2014.

[31] A. S. Lengkana, J. Tangkudung, and A. Asmawi, "The effectiveness of thigh lift exercises using rubber on the ability of acceleration on sprint runs," in Journal of Physics: Conference Series, 2019, vol. 1318, no. 1, p. 12031.

[32] T. Purdom, L. Kravitz, K. Dokladny, and C. Mermier, "Understanding the factors that effect maximal fat oxidation," J. Int. Soc. Sports Nutr., vol. 15, no. 1, pp. 1-10, 2018.

[33] M. Gäbler, O. Prieske, T. Hortobágyi, and U. Granacher, "The effects of concurrent strength and endurance training on physical fitness and athletic performance in youth: a systematic review and meta-analysis," Front. Physiol., vol. 9, p. $1057,2018$.

[34] A. K. Nayak, "Effect of hand-eye coordination on motor coordinative ability of tribal adolescents," Int. J. Phys. Educ. Sport. Heal., vol. 2, no. 2, pp. 328-330, 2015.

[35] E. Burhaein, B. K. Ibrahim, and R. Pavlovic, "The Relationship of Limb Muscle Power, Balance, and Coordination with Instep Shooting Ability: A Correlation Research in Under-18 Football Athletes," International Journal of Human Movement and Sports Sciences., vol. 8, no. 5, pp. 265-270, 2020. DOI: 10.13189/saj.2020.080515.

[36] G. Erim and M. Caferoglu, "Determining the Motor Skills Development of Mentally Retarded Children through the Contribution of Visual Arts.," Univers. J. Educ. Res., vol. 5, no. 8, pp. 1300-1307, 2017.

[37] J. D. Crawford, W. P. Medendorp, and J. J. Marotta, "Spatial transformations for eye--hand coordination," $J$. Neurophysiol., 2004.

[38] A. Rudzitis, O. Kalejs, and R. Licis, "Model characterizing sports game referees," in SHS Web of Conferences, 2014, vol. 10 , p. 39.

[39] A. Talukder, M. G. R. Alam, A. K. Bairagi, S. F. Abedin, H. T. Nguyen, and C. S. Hong, "Threshold estimation models for influence maximization in social network," pp. 888-890, 2016.

[40] R. de la Vega, D. Carrasquilla López, E. Ortiz, R. Ruiz, and M. Armenteros Gallardo, "Influence of reaction time and movement in the performance of football referees," 2017.

[41] A. Kovari, J. Katona, and C. Costescu, "Quantitative analysis of relationship between visual attention and eye-hand coordination," Acta Polytech. Hungarica, vol. 17, no. 2, pp. 77-95, 2020.

[42] F. Van Halewyck, A. Lavrysen, O. Levin, M. P. Boisgontier, D. Elliott, and W. F. Helsen, "Both age and physical activity level impact on eye-hand coordination," Hum. Mov. Sci., vol. 36, pp. 80-96, 2014.

[43] M. Paul, S. Kumar Biswas, and J. Singh Sandhu, "Role of sports vision and eye hand coordination training in performance of table tennis players," Brazilian $J$. Biomotricity, vol. 5, no. 2, 2011.

[44] A. Karaçam and A. Pulur, "Examining the relationship between referee self-efficacy and general self-efficacy levels of basketball referees in terms of certain variables," J. Educ. Train. Stud., vol. 5, no. 8, pp. 37-45, 2017.

[45] M. M. Mobius, M. Niederle, P. Niehaus, and T. S. Rosenblat, "Managing self-confidence: Theory and experimental evidence," 2011.

[46] R. D. Samuel, C. Englert, Q. Zhang, and I. Basevitch, "Hi ref, are you in control? Self-control, ego-depletion, and performance in soccer referees," Psychol. Sport Exerc., vol. 38, pp. 167-175, 2018. 